\title{
Development of a Mobile Learning for Digital Logic Gates in Vocational Schools
}

\author{
Asni Tafrikhatin, Farah Puspa Marsyaly, Moh. Khairudin \\ Universitas Negeri Yogyakarta \\ Yogyakarta, Indonesia \\ asni20081992@gmail.com
}

\begin{abstract}
This paper was aimed to know the impact of mobile learning media for the subject of basic logic gates in learning process at second grade student of vocational high school. This study was development using the Pressman's Waterfall approach to create the software. A Mobile learning media for the mastery of basic logic gates is made through a black box test with status declared is well. Rating the performance of mobile learning media, includes two indicators are derived from the dimensions of functionality, namely suitability of the media and accuracy of the navigation keys. To asses a feasibility of the media includes two aspects, namely the ISO 9126 standard software and teaching materials assessment component. Regarding the ISO 9126 standards can be concluded the performances of functionality is categorized very well, while realibility and usability are categorized as good.
\end{abstract} Media

Keywords- Basic Logic Gates; Mobile Learning; Learning

\section{INTRODUCTION}

The development of Curriculum in Indonesia for the years of 2006 namely Curriculum of Education Group Level (Kurikulum Tingkat Satuan Pendidikan, KTSP) and then at year of 2013 the curriculum was improved to Curriculum of 2013. In the Curriculum of 2013 supports teachers to make more preparations before teaching and learning process (TLP). This situation make teachers necessary several additional equipments. One of the uquipment to help teachers for making preparation before TLP such as refers to online resources. In the school normaly was provided the free access of internet. Several facilities can be used to make more easy for the teacher and student in TLP such as for giving the quiz using mobile phone [1]. In addition students become less motivated to follow the teaching and learning process, to solve this problem it is necessary to transform conventional teaching classroom to learner-centred teaching classroom that can be used multimedia module [2]. To develope a good TLP, a teacher should be make a proffesional development because it is necessary required by teachers [3]

Most of factors can support to students' achievement. One of factor that can be contribute for achieving the subject competence is teacher performances in TLP. In otherway, presented a learning module of computer numerically control GSK 983 machines to enhance students' learning outcomes [4]. To support the performance of teachers in the classroom, the teacher must prepare all kinds of learning tools for learning to walk according to the learning objectives to be achieved. In otherside, e-learning can be seen by e-module. The development of e-module development for the subject of measuring instruments and measurement in electronics engineering education. The results for that study explored the e-module was respectively considered feasible and quite feasible [5].

The intensity of students holding a smartphone longer than textbooks is also a result of the low quality of education in Indonesia. This proves that some vocational students have started dependence by mobile phone. The statement was in line with Tessa [6], findings suggest that students seem to be addicted to their cell phones, with 64 percent of students observed on campus interacting with their device one way or another. Nevertheless, a survey of students found that they believe that the need of self-gratification achieved through excessive cell phone use has negative psychological effects on them.

Students are still not happy to read a book because of the impracticality of books, so the culture of reading in students becoming obsolete. Most of the students do the work just to find material in google and take resources from existing blog. Though sometimes the accuracy of the science presented in the blog is not necessarily true so it must open some blogs to ascertain the truth. The increase in internet users continues to increase due to the growing number of data plans offered by the Company's Internet Service Provider and many public places that provide free $\mathrm{Wi}-\mathrm{Fi}$ access.

Based on the existing problems is necessary to develop an application developed with the Android operating system. Applications built Android is expected to meet the needs of learning materials so as to make the assessment process to be very easy, effective and flexible. This application is expected to be used anywhere and anytime by vocational students. The material will be tested contained some competence in digital material covers basic logic gates and Boolean algebra that highlight the characteristics of the circuit and circuit analysis skills. The materials are basic materials for students Engineering Program Audio Video, so students should have a strong basic material.

\section{BASIC THEORY}

\section{A. Instructional Media}

According to Rodger [7] states that a good media to fulfill four main requirements: (1) Attention: attention of learners 
can always be maintained, so it requires the right strategy to attract the attention of students, (2) Relevance: learning media should be designed to demonstrate that their information can be needed when learners work or in everyday life, (3) Belief: learning media is expected to convince the students that the students are able to learn the material so the motivation will be awakened, and (4) Satisfaction: learners should be satisfied with a learning experience that students have acquired. Good learning media should be able to attract the attention of students, the instructional media also have compatibility with existing material, and can convince the students so that students were satisfied with the learning media.

The principles of instructional media are (1) the use of the media must be in accordance with the needs of learning, (2) the media is not for entertainment but to learn, (3) the media should have easy access and flexible, (4) media is a creative self-expression, (5) media sparked critical thinking, (6) the selection of media should reflect the goals and objectives of the results produced, (7) the media should be connected to real life, and (8) media produced must be qualified and have relevance to the learning materials[8]. Knill [9] argues that the process of learning to use the media has several benefits including: (1) can illustrate the material in real life, (2) explain the material can be more detailed, (3) can overcome the problem if there is a problem in real life, (4) spur critical thinking in students, (5) can be shared with other teachers, and (6) the students can be actively involved in the learning process. Eisa [10] also suggests learning media has two effects according to which media able to give the impression of reality and the media were able to develop the cognitive and psychomotor abilities. Yuyus [11] states that the general characteristics of the media are (1) physical education media referred to hardware that is an object that can be seen, heard, or touched with the five senses; (2) educational non-physical media called the software that is the content of the message contained in the hardware which is the content to be conveyed to the students; (3) the medium of education in the visual and audio; (4) tools in the learning process; (5) used in the context of communication and interaction of teachers and students in the learning process; (6) media that can be used in bulk; and (7) attitude, organization, strategy, and management associated with the implementation of a science. Based on some of the expert opinion can be concluded that the instructional media must be adapted to the learning material, helping learners to give the impression of reality, triggering critical thinking in learners, and learners can be actively involved in the learning process.

Based instructional media technology should enable students to learn independently, the material that is structured horizontally (complementary) so that students can learn the material easier to understand. Learning to use technologybased instructional media should have connectivity and interactivity among learners, learners with teachers, and learners with educational institutions to be controlled from one another. Materials on technology learning media should also be all time and using a certain scale to be used not only for personal entertainment but can be used by anyone, so that the media sought is open source. Media technology-based learning is alternative means to make the learning process due to several things including: (1) easy to make in the learning process, (2) more attractive for learning, and (3) can be corrected at any time [12].

\section{B. Mobile Learning}

Georgiev [13] reveals that in order to realize mobile learning as a new stage for realizing the advancement of distance learning (d-learning) and e-learning, d-learning is learning that takes place separately between teachers and learners both distance and time while e-learning is a technology-based learning. Georgiev [13] describes the relationship between the d-learning, e-learning and m-learning is as follows as presented at Figure 1.

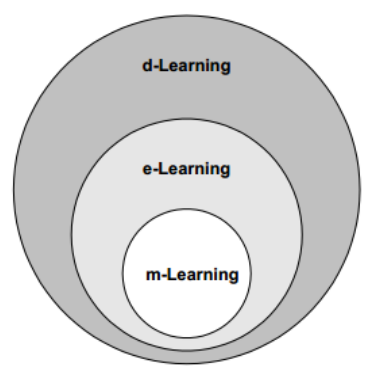

Fig. 1. Relationship between the d-learning, e-learning and m-learning [13]

Characteristics of mobile learning is (1) are accessibility: information is always available whenever learners need to use, (2) immediacy: the information can be directly taken by learners, (3) interactive: learners can communicate with peers, teachers and experts, (4) context awareness: it can give the impression of a real, (5) permanency: its information, and (6) flexible learning: portability [14]. Mobile learning is expected to provide ease of access to students to learn anywhere. Mobile learning can also help students to understand the subject matter in the mobile learning because there are pictures or videos that can give a real impression on students so that students do not concoct to understand the new material.

According Koole [15], The Framework for the Rational Analysis of Mobile (FRAME) explains that mobile learning has three aspects: device, learners, and social. These three aspects can be described at Figure 2 .

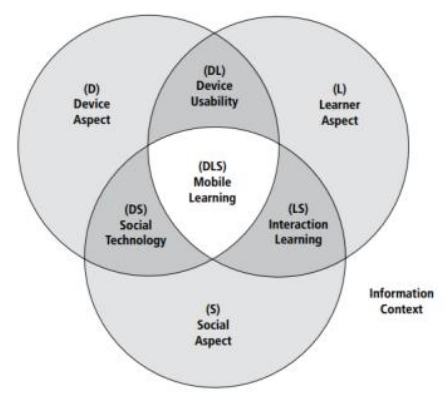

Fig. 2. Venn Diagram Three Aspects of Mobile Learning (Source: Koole, 2009: 27)

Based on Figure 2, slice of device aspect with the learner is a device usability, whereas slices of learner aspect with social aspect is learning interactions, If the slices of the social aspect with the device aspect is a social technology. Mobile learning 
is a slice of device usability, social technology, and the interaction model.

\section{Android Operating System}

Android operating system is Linux-based open operating system made for touch screen mobile devices such as smartphones and tablets. Android was developed in October 2003 by Android Rubin, Rich Miner, Nick Sears, and Chris White. On August 17, 2005 Android was acquired by Google. Since then, a growing number of wireless equipment in the various countries using the Android operating system, such as tablets, net-book, set-top boxes and even cars are also adopting the android operating system [16]. Android provides an open platform for developers to create their own applications, development is formed Open Handset Alliance (OHA) a consortium of 34 companies hard device, software device, and telecommunications, including Google, HTC, Intel, Motorola, Qualcomm, T-Mobile, and Nvidia.

Android operating system also is open source so that anyone can easily create an application in accordance with what is desired and needed. Android platform has three advantages, namely a complete, open, and free. Android platform is very easy for developers to create applications that are creative. Android also provides software to develop applications for free without a license attached.

\section{Standards ISO 9126 Software}

Quality application development cannot be separated from the standard is used as an indicator of the feasibility of a software. some companies software developers are required to meet the standards of eligibility application, not separated from the International Standards Organization, or better known as (ISO), issuing eligibility standard software that is packaged in ISO 9126. ISO 9126 (ISO / IEC FDIS 9126-1) classifies quality testing software based on three categories namely: (1) quality framework models, (2) quality models for external and internal quality, (3) quality models for quality in use. In overall category that should be owned by the software developer is the quality internal and external covers 6 characteristics.

Every point in the category of internal and external value of this quality which can be used as a standard reference for software testing. Translation of each points on ISO 9126 will be explained as follows: (1) functionality : software must have the ability capable of functioning in accordance needs and specific program commands, (2) reliability : software can work stably and safely, (3) stability : software can be used easily by the user, (4) efficiency : software should have a response, time, resources, in accordance with software needs, (4) maintainability : software can be changed modified adjusted to the needs developers, and portability : software is portable or easily moved, used in devices other.

\section{METHODS}

This study was conducted by the research approach development. The development model used is the Waterfall development model Roger S. Pressman. Model development of Waterfall Pressman used in this study there are four stages, namely: (1) communication, observations and interviews with teachers Subjects Basic Electronics to get the media specifications that can be solved using the medium of mobile learning are being developed, (2) planning, will be generated document user requirements or can be regarded as data relating to the wishes of the user or users in making software, including plans to do, (3) modeling, done by making the design data structures, software architecture, interface representations in the form of story board, and detail (algorithm) procedural flowchart form, (4) construction, carried out in two stages, namely coding and testing.

Testing is done with an instrument validation by expert judgment. Furthermore, the alpha testing and testing software based on compliance with the ISO 9126 standard which includes three indicators, namely functionality (black box testing), reliability, and usability (beta testing). The data in this study were drawn by using observation, interview, questionnaire, and test. Questionnaire consisted of black box testing, alpha testing, and beta testing. The performance of the unknown of black box testing against six respondents.

Feasibility known of assessment materials experts, media experts, and the suitability of the standard ISO 9126 that functionality (black box testing), reliability and usability (beta test). The impact of media use of mobile learning basic logic gates known from the calculation of the value of the test. Black box testing questionnaires were prepared using the appropriate assessment and appropriate. Scale assessment questionnaire applied in black box testing are 0 and 1 . The questionnaire used in the feasibility of data collection instruments based on the alpha testing and beta testing using a Likert scale with four answer options.

This study uses data analysis techniques of qualitative and quantitative descriptive. The data analysis was conducted to determine the feasibility level categories based learning media respondents' statements. Determining the average score of respondents categorized as very worthy, worthy, worthy or less worthy enough is done to make the interval score ratings. Interval score is then converted into a score of 0-100 vulnerable ratings with the formula, assessment score $=$ (score obtained / maximum score) x 100.

\section{RESULT AND DISCUSSION}

The development of mobile media on media instructional is done by Waterfall development model adopted by Pressman. Waterfall development model used in this study include four stages, namely: (1) communication, (2) planning, (3) modeling, and (4) construction. The discussion of each stage is performed in this study are discussed as follows. Stage communication, conducted to determine the product specifications. At this stage produces shaped mobile learning media file.apk, 17,21 MB media capacity, resolution of $1024 \times 768$ pixels, and can be used on Android smartphones. 
Planning stage, made to design a schedule for the manufacture of mobile learning media. The results obtained at this stage of the research plan. Research plan can be seen in Table 1.

TABLE I. PLAN RESEARCH

\begin{tabular}{|c|l|c|}
\hline No. & \multicolumn{1}{|c|}{ Activity } & Time \\
\hline 1 & Make story board & August \\
\hline 2 & Make layout & September \\
\hline 3 & $\begin{array}{l}\text { Implementation layout to } \\
\text { Android Studio }\end{array}$ & September \\
\hline 4 & Input material content & October \\
\hline 5 & Make navigation & October-November \\
\hline 6 & Make coding & November \\
\hline 7 & Revision & December \\
\hline
\end{tabular}

Modeling phase, focusing on four workmanship, namely data structures, software architecture, interface representations, and detail (algorithm) procedural. Flow modeling stage craftsmanship can be presented in Figure 3 below.

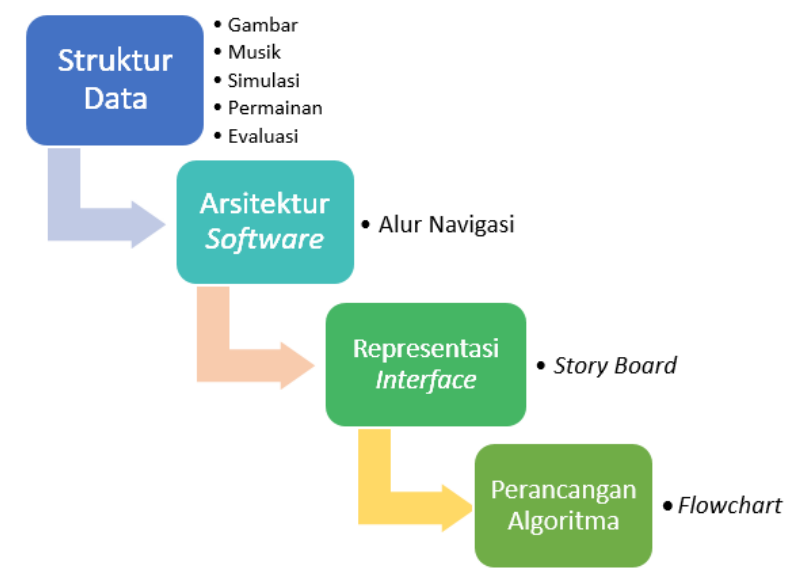

Fig. 3. Flow Modeling Phase

(1) The data structure used in mobile learning media includes learning materials, instructional media supporting images, music, simulations, games, and evaluation. (2) Architecture software for mobile learning media can be seen in Figure 4.

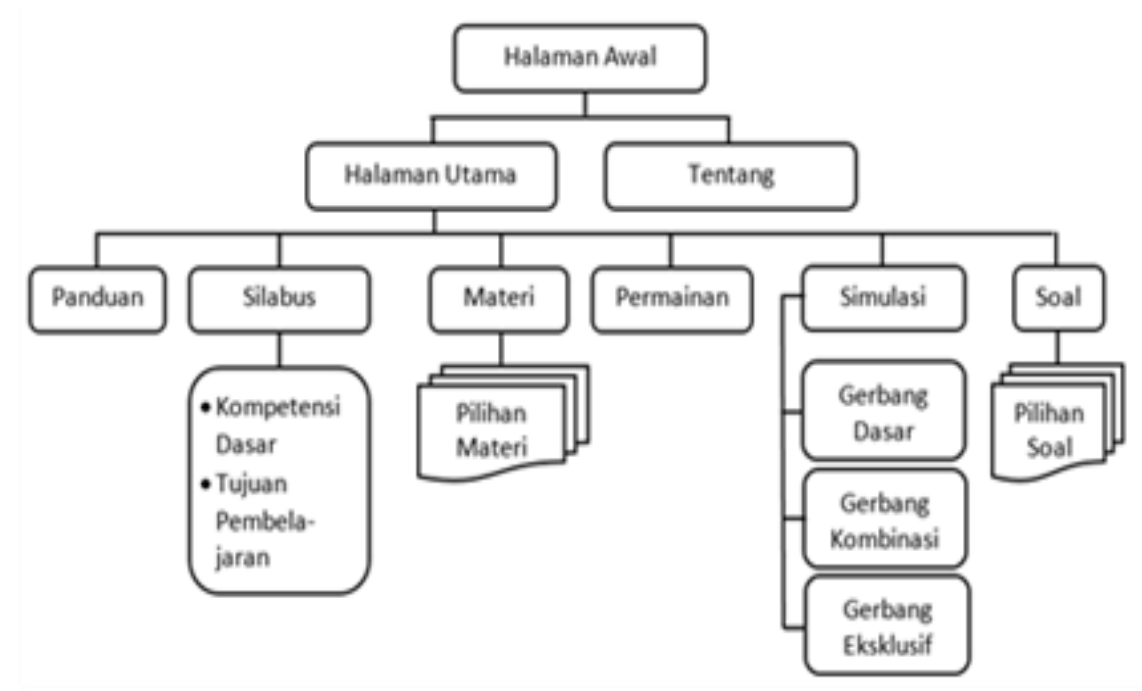

Fig. 4. Architecture of Software Mobile Instructional Media

(3) Representation interface done by creating a story board to facilitate mobile learning media making basic logic gates. (4) The design of the algorithm described in detail the components of software made in the form of a flowchart. The final design view is created using CorelDraw software assistance X7. Figure 5 displays design logic gates elementary for mobile learning media. 


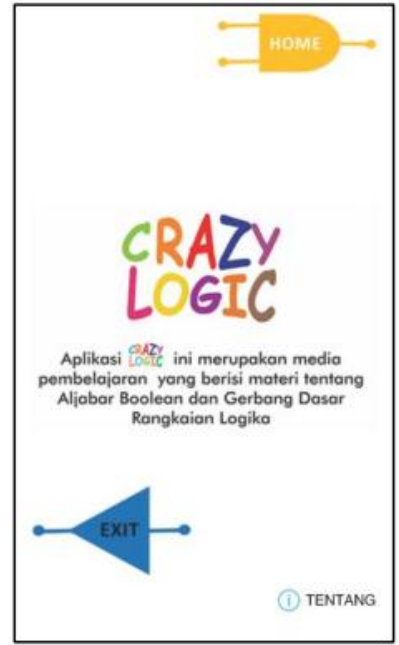

Fig. 5. Mobile Learning Media Display Design Logic Gates Elementary

Stage construction, such as coding and testing, for the coding is done using software Android Studio. The first testing phase is validation of the instrument performed with the construct validation (expert judgment) that consulted with two experts research instrument that is a lecturer of Electrical Engineering of Education in Engineering Faculty UNY.

Tests are second to test the feasibility of materials and media (Alpha Testing). The test material consisted of two aspects: the substance of the material, and instructional design with 16 point ratings. Rate item with Likert scale of 1-4 and then converted into a range of $0-100$. The results of expert assessment of the material can be seen in Table 2 .

TABLE II. EXPERT ASSESMENT OF MATERIAL

\begin{tabular}{|c|c|c|}
\hline \multirow{2}{*}{ Resp } & \multicolumn{2}{|c|}{ Score/Aspect } \\
\cline { 2 - 3 } & Material Substance & Instructional Design \\
\hline Media & 75,00 & 87,50 \\
Expert 1 & & 84,37 \\
\hline $\begin{array}{c}\text { Media } \\
\text { Expert 2 }\end{array}$ & 71,87 & 85,93 \\
\hline Average & 73,44 & \multirow{2}{*}{} \\
\hline
\end{tabular}

Table 2 can be explained that both media experts claim this app worthy to serve as a medium of learning. Media material on the feasibility of mobile learning for competence basic logic gates include aspects of material substance and design aspects of learning. Aspects of the substance of the material is divided into four dimensions, namely truth, depth, present, and legibility. While aspects of instructional design is divided into eight dimensions, namely the title, competencies, learning objectives, materials, sample questions, test, compilers, as well as references.

Testing the media consist of two aspects: the ISO 9126 standard software that includes a three-dimensional functionality, reliability, and usability. Rate aspect of teaching materials covering only one dimension that is visual communication with a whole there is a 24 point assessment. Rate item with Likert scale of 1-4 and then converted into a range of 0-100. Media expert assessment results can be seen in Table 3.

TABLE III. ASSESSMENT BASED ISO 9126

\begin{tabular}{|c|c|c|c|c|}
\hline \multirow{2}{*}{ Resp } & \multicolumn{3}{|c|}{ Score/Aspect } & \multicolumn{1}{c|}{$\begin{array}{c}\text { Comm. } \\
\text { visual }\end{array}$} \\
\cline { 2 - 4 } & \multicolumn{3}{|c}{ Comfimity with ISO 9126 } & \\
\cline { 2 - 4 } & Functionality & Reliability & Usability & \\
\hline $\begin{array}{c}\text { Media } \\
\text { Expert } \\
1\end{array}$ & 83,33 & 75,00 & 83,33 & 70,83 \\
\hline $\begin{array}{c}\text { Media } \\
\text { Expert } \\
2\end{array}$ & 79,17 & 75,00 & 83,33 & 70,83 \\
\hline Average & 81,25 & 75,00 & 83,33 & 70,83 \\
\hline
\end{tabular}

Table 3 illustrates the aspect of compliance with the ISO 9126 standard software includes dimensional functionality, reliability, and usability while on aspects of teaching material assessment component measuring about visual communication display. This application has the endurance performance and the performance of these applications either. This application also has a pretty good performance durability. But to see this application of visual communications needed to be improved.

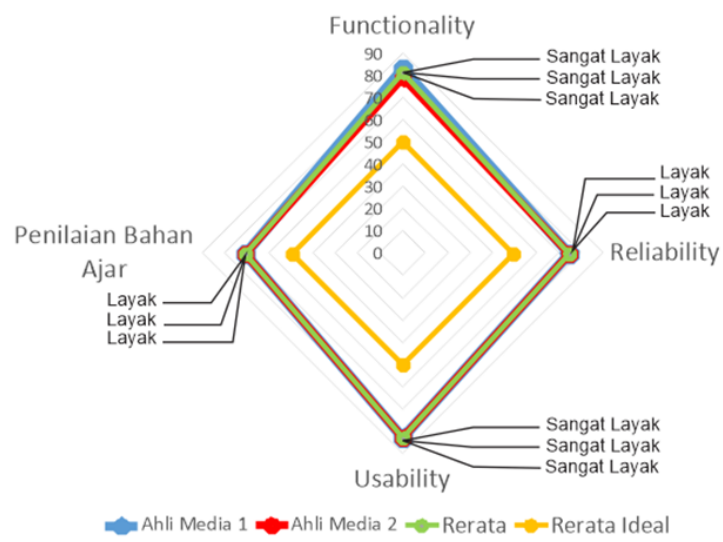

Fig. 6. Media Feasibility Assessment

Figure 6 illustrate the compliance with standards ISO 9126 includes three indicators of functionality, reliability, and usability. First, the functionality (black box testing) ISO standard 9126. The results obtained black box testing mean score of 100 on the indicator of the suitability of the media and the accuracy of the navigation keys, so that mobile learning media included in the category of very good. Second namely reliability, obtained from the assessment of media questionnaire on indicators of reliability obtain the mean average value of 75.00 is included in the category of eligible. Third namely usability (beta testing) is divided into four assessment that the average value of the indicator operability 
scored 73.25 categorized as good, the indicator learn ability scored 72.50 categorized as good, the indicator understandability scored 73.33 categorized as good, and the indicator attractiveness scores 75.25 including the category of very good. The results of beta testing on all aspects of the score obtained 73.45 categorized as good.

\section{CONCLUSION}

The results are supported by the performance of mobile learning media for the mastery of basic logic gates which are produced through a black box test, it is declared very good with an average value of 100 . Rating the performance of mobile learning media, includes two indicators that are derived from the dimensions of functionality, namely the suitability of media and the accuracy of the navigation key. Besides supported by the acquisition of a very good performance, mobile learning media for the mastery of basic logic gates otherwise have been declared vvery decent through alpha testing materials experts and media experts. Testing the feasibility of material includes two aspects namely the substance of the matter and instructional design. Testing the feasibility of the media covers two aspects namely the ISO 9126 standard software and component of teaching materials assessment. Compliance with ISO 9126 standards, namely: functionality (black box testing) with the result very good, the reliability of the expert assessment of media categories good, and usability (beta testing) with the results of good.

\section{REFERENCES}

[1] M. Hosein and L. Bigram, "An Educational Bluetooth Quizzing Application in Android," Int. J. Wirel. Mob. Networks, vol. 5, no. 6, pp. 69-78, 2013.

[2] Y. W. Li, "Transforming Conventional Teaching Classroom to Learner-Centred Teaching Classroom Using Multimedia-Mediated Learning Module," Int. J. Inf. Educ. Technol., vol. 6, no. 2, pp. 105112, 2016.

[3] I. W. Djatmiko, "A Study on The Empowering Teachers' Professional Development and Quality Assurance to Increase Teachers' Effectiveness in Vocational Secondary Schools," J. Pendidik. Teknol. dan Kejuru., vol. 23, no. 2, pp. 144-151, 2016.

[4] Martono and Wagiran, "Developing A Learning Module of Computer Numerically Control GSK 983 Machines to Enhance Students , Learning Outcomes," J. Pendidik. Teknik. dan Kejuruan., vol. 23, no. 20, pp. 184-190, 2016.

[5] N. Fajaryati and P. W. Pranoto, "E-Module Development For The Subject of Meaasuring Instruments and Measurement in Electronics Engineering Education," J. Pendidik. Teknol. dan Kejuru., vol. 23, no. 2, pp. 191-199, 2016.

[6] T. Jones, "Students' Cell Phone Addiction and Their Opinions," Elon J. Undergrad. Res. Commun., vol. 5, no. 1, pp. 74-80, 2014.

[7] D. L. Rodgers and B. J. Withrow-Thorton, "The Effect of Instructional Media on Learner Motivation," International Journal of Instructional Media, vol. 32, no. 4. pp. 333-343, 2005.

[8] J. Gejel, "Media Based Learning Lessosns Learned and Open Inspiration Part 1," EU LABlearning, vol. 1, pp. 1-35, 2012.

[9] O. Knill, "Benefits and Risks of Media and Technology in the Classroom," Itccm. pp. 1-10, 2008.

[10] H. Eisa H.R, Instructional Design and Media Selection. Twente University Press, 2001.

[11] Yuyus Suherman, "Pengembangan Media Pembelajaran bagi ABK." UPI Bandung, pp. 64-80, 2009.

[12] Sapto Haryoko, "Efektivitas Pemanfaatan Media Audio-Visual sebagai Alternatif Optimalisasi Model Pembelajaran,” J. Edukasi @Elektro, vol. 5, pp. 1-10, 2009.

[13] Tsvetozar Georgiev, "M-Learning: A New Stage of E-Learning," in International Conference on Computer Systems and Technologies, $\mathrm{p}$. 28.1-28.5, 2004.

[14] S. Kumar, "E- and M-Learning: A Comparative Study," Int. J. New Trends Educ. Their Implic., no. July, pp. 65-78, 2013.

[15] M. L. Kool, Mobile Learning Transforming the Delivery of Education and Training, vol. 3, no. 2. 2009.

[16] N. Steele, J., \& To, The Android Developer's Cookbook: Building Applications with the Android SDK. US: Pearson Education, 2010. 